\title{
Implementasi Program Gerakan Orangtua Mengajar Untuk Meningkatkan Motivasi Belajar
}

\author{
Diah Rina Miftakhi \\ STKIP Muhammadiyah Bangka Belitung \\ Email: diah.rinamiftakhi@stkipmbb.ac.id, \\ Maulina Hendrik \\ STKIP Muhammadiyah Bangka Belitung \\ Email: maulina.hendrik@stkipmbb.ac.id
}

(Diterima: 02-Juli-2018; direvisi: 06-Oktober-2018; dipublikasikan: 29-Desember-2018)

\begin{abstract}
Abstrak. Penelitian ini bertujuan untuk mendeskripsikan gerakan orangtua mengajar di sekolah dalam rangka untuk meningkatkan motivasi belajar peserta didik dengan melibatkan orangtua dalam program sekolah. Program ini dilaksanakan salah satu tujuannya adalah untuk mengurangi angka putus sekolah. Penelitian ini menggunakan pendekatan kualitatif naturalistik. Pengumpulan data dilakukan melalui observasi, wawancara, dan dokumentasi. Subyek penelitian ini antara lain kepala sekolah, guru, pegawai, orangtua dan peserta didik. keabsahan data dilakukan dengan triangulasi, perpanjangan waktu penelitian dan ketekunan pengamatan. Hasil penelitian menunjukkan bahwa implementasi gerakan orangtua mengajar yang sudah dilaksanakan di SD Negeri 10 Pangkalanbaru sangat efektif dilaksanakan untuk meningkatkan motivasi belajar. Hal ini dapat dilihat dari dukungan yang diberikan oleh pihak sekolah maupun pihak orangtua. Program yang sudah dilaksanakan yaitu program carier day. Program dilaksanakan untuk menumbuhkan semangat dan motivasi peserta didik dalam belajar supaya tidak mengalami putus sekolah dan memiliki cita-cita untuk melanjutkan pendidikan ke jenjang yang lebih tinggi.Tugas orangtua dalam program gerakan orangtua mengajar ini adalah mereka diminta untuk memaparkan serta menceritakan profesi yang selama ini mereka lakukan. Profesi tersebut juga akan kita kaitkan dengan mata pelajaran yang di pelajari oleh peserta didik di sekolah.
\end{abstract}

\section{Kata kunci: Gerakan Orangtua Mengajar; Motivasi Belajar}

\begin{abstract}
This study aims to describe the movement of parents teaching in schools in order to improve the motivation of learners by involving parents in school programs. This program is implemented one of the goals is to reduce the number of school dropouts that occur in coastal areas. This research uses qualitative naturalistic approach. Data collection is done through observation, interview, and documentation. The subjects of this study include principals, teachers, employees, parents of learners and learners. the validity of data is done by triangulation, prolongation of research and observation persistence. The results showed that the implementation of parental teaching movement that has been implemented in SD Negeri 10 Pangkalanbaru very effective implemented. The program that has been implemented is the carier day program. The program is implemented to foster the spirit and motivation and do not experience dropping out and have aspirations to continue their education to a higher level. The parents' tasks of the students in this parenting teaching program is that they are asked to describe and tell the profession all this time they do. The profession will also be associated with the subjects that are learned by the students in the school.
\end{abstract}

Keywords: Teaching parent movement; Motivation learning 


\section{PENDAHULUAN}

Program gerakan orangtua mengajar merupakan suatu program yang dilaksanakan di sekolah dalam rangka untuk mendukung program pembelajaran. Program ini dilaksanakan salah satu tujuannya adalah untuk meningkatkan motivasi belajar peserta didik supaya peserta didik lebih semangat dalam belajar dan diharapkan program yang dilaksanakan ini dapat mengurangi angka putus sekolah. Dalam kegiatan ini pihak sekolah akan melibatkan orangtua dalam melakukan proses kegiatan belajar mengajar di kelas yang fokus kegiatannya dilakukan untuk menumbuhkan semangat serta motivasi belajar peserta didik. Grolnick, Friendly \& Bellas (dalam Wentzel \& Wigfield, 2009: 282) menyatakan terdapat tiga tipe keterlibatan orangtua yaitu: (1) keterlibatan perilaku; (2) keterlibatan intelektual; dan (3) keterlibatan personal.

Keterlibatan orangtua dalam mengajar relevan dengan penelitian yang pernah dilakukan oleh Junianto D dan Wagiran tahun 2013, bahwa keterlibatan orangtua dalam pendidikan anak berpengaruh terhadap motivasi berprestasi. Hal ini menunjukkan bahwa segala jenis keterlibatan orangtua dalam pendidikan yang menyangkut keterlibatan secara personal, keterlibatan pedagogik, dan komunikasi dengan sekolah sangat mempengaruhi motivasi peserta didik. Pendidikan orangtua dan banyaknya waktu yang dialokasikan untuk anak merupakan hal penting dalam meningkatkan keterlibatan orangtua. Pendapat ini mengindikasikan bahwa kedekatan dan sikap terbuka orangtua terhadap anak merupakan hal yang harus diperhatikan oleh setiap orangtua.

Kegiatan gerakan orangtua mengajar dapat dilakukan dengan berbagai bentuk kegiatan yang berbeda-beda. Kegiatan gerakan orangtua mengajar juga dapat dilaksanakan didalam kelas maupun diluar kelas. Partisipasi orangtua peserta didik di sekolah sangatlah penting. Baik itu dalam kaitannya dengan peserta didik secara langsung maupun dalam hubungan kerjasama untuk meningkatkan pembelajaran. Pembelajaran memadukan secara utuh potensi peserta didik yaitu sikap, pengetahuan dan ketrampilan. Seluruh pembelajaran dirancang untuk menstimulus ketiga ranah tersebut dengan menggunakan berbagai metode dan sarana belajar. Setiap pokok bahasan harus berupaya menarik minat anak terhadap pokok bahasan serta membimbing mereka untuk masuk pada dunia aplikasinya.

Slavin (2011: 135) menyatakan peran sekolah untuk meningkatkan keterlibatan orangtua diantaranya: (1) kunjungan keluarga pada awal semester untuk mengetahui dukungan keluarga, kondisi psikologi dan kecerdasan peserta didik; (2) menyampaikan berita berkala yang sering kepada orangtua, untuk mengetahui tingkat keberhasilan pembelajaran; (3) lakukan lokakarya orangtua, dengan mengundang orangtua ke sekolah sehingga guru/ sekolah dapat menjelaskan program pembelajaran dan harapan guru/sekolah dapat membantu orangtua memahami bagaimana cara mendukung pembelajaran anak; (4) sampaikan berita positif ke rumah melalui telephon, sehingga menghasilkan dukungan positif dan meningkatkan kemungkinan perilaku tersebut berlanjut; (5) ajak anggota keluarga menjadi sukarelawan; dan (6) jadikan orangtua sebagai mitra. Kegiatan ini akan sangat berpengaruh kepada prestasi peserta didik. Hal ini terjadi karena peserta didik yang senantiasa mendapat dukungan orangtua, mempunyai kepercayaan diri dan keinginan maju yang tinggi.

Keterlibatan orangtua dalam pendidikan anak sangat berpengaruh terhadap prestasi belajar. Sebagaimana kita ketahui keterlibatan orangtua dalam pendidikan anak, terbagi menjadi dua kelompok, yaitu keterlibatan orangtua dalam keluarga dan keterlibatan orangtua terhadap sekolah. Penelitian Altschul (2011: 169) menemukan bahwa keterlibatan orangtua dalam keluarga memiliki pengaruh dominan terhadap prestasi dibandingkan dengan keterlibatan orangtua dalam pendidikan terhadap sekolah. Interaksi di dalam keluarga ditandai dengan komunikasi yang baik. Komunikasi yang di maksud adalah komunikai dua arah. Sehingga peserta didik dan orangtua saling mengetahui keinginan/harapan masing-masing. Komunikasi menyangkut aspek fisik dan mental. Aspek fisik berarti bertemu secara fisik antara anak dan orangtua, sedangkan aspek mental meliputi merasa diperhatikan, disayangi, peduli dan lainlain.

Program kegiatan hari karir merupakan program memperkenalkan dunia kerja melalui narasumber orangtua peserta didik hal ini dilakukan agar peserta didik memperoleh informasi dan gambaran mengenai pekerjaan dilingkungannya serta dapat mengindentifikasi bakat, minat juga potensi karir untuk dirinya 
kedepan. Peran atau tugas orangtua dalam program ini adalah, orangtua diminta untuk menumbuhkan semangat dan motivasi belajar peserta didik melalui pengalaman kesuksesan yang sudah diperoleh orangtua selama ini. Orangtua diharapkan dapat menceritakan pengalaman profesi atau pekerjaan yang dilakukan selama ini, mulai dari bagaimana untuk dapat meraih kesuksesan, kendala-kendala yang dihadapi pada saat bekerja, serta pendidikan yang harus ditempuh untuk dapat mendukung kesuksesannya tersebut.

Sehingga dari beberapa penelitian yang sudah pernah dilakukan dan dari beberapa teori yang disampaikan oleh beberapa ahli tersebut dapat disimpulkan, bahwa orangtua merupakan pendidik utama dan pertama bagi keberhasilan anak dalam belajar. Selain itu kerjasama serta keterlibatan orangtua dengan pihak sekolah sangat penting. Sebab program-program yang ada di sekolah tanpa mendapatkan dukungan dari pihak orangtua dalam melaksanakannya tidak akan dapat berhasil. Salah satu program yang saat ini sedang banyak dilakukan oleh pihak sekolah dengan pihak orangtua yaitu program gerakan orangtua mengajar.

\section{METODE}

Penelitian ini dikembangkan dengan pendekatan kualitatif naturalistik. Sugiyono (2016: 1) mengatakan bahwa metode penelitian kualitatif sering disebut metode penelitian naturalistik karena penelitiannya dilakukan pada kondisi yang alamiah. Subyek dan obyek penelitian ini secara purposive dimaksudkan untuk mendapatkan deskripsi keseluruhan bentuk yang ada di lapangan supaya mendapat informasi optimal mengenai unsur-unsur yang diteliti dan tidak dimaksudkan untuk mendapatkan generalisasi. Maka sumber informasi dalam penelitian ini dikelompokan ke dalam (1) jaringan sumber informasi kunci yang terdiri dari Kepala sekolah SD Negeri 10 Pangkalanbaru dan (2) jaringan informasi pendukung yaitu guru, pegawai dan siswa sebagai penerima jasa dan pelanggan primer SD Negeri 10 Pangkalbaru.

Teknik dan instrumen pengumpulan data dalam penelitian ini antara lain menggunakan tehnik observasi, wawancara, dan dokumentasi. Keabsahan data dilakukan dengan menggunakan metode triangulasi, perpanjangan keikutsertaan dan ketekunan pengamatan. Teknik analisis data dalam penelitian ini lebih menekankan proses daripada hanya sekedar hasil, dan berpedoman kepada analisis data akhir yang dilakukan dengan langkah-langkah yang berupa reduksi data, display data, dan kesimpulan/verifikasi (Sugiyono, 2016: 91).

\section{HASIL DAN PEMBAHASAN}

\section{Implementasi Gerakan Orangtua Mengajar}

Orangtua di dalam keluarga mempunyai tanggung jawab penuh atas perkembangan anakanaknya, terutama dalam bidang pendidikan orangtua adalah yang paling bertanggung jawab didalam pendidikan. Ini berarti peran orangtua di dalam pendidikan tidak dapat diabaikan begitu saja. Justru para orangtualah yang merupakan pendidik pertama bagi anak untuk menuju keberhasilan atau tidak berhasilnya pendidikan formal anak. Setiap orangtua pasti mendambakan anaknya cerdas dan berprestasi, disinilah peran orangtua dituntut untuk bisa memotivasi anak agar mampu berhasil dalam belajar di sekolah dan mampu memberikan dorongan kepada anak dalam meningkatkan prestasinya.

Motivasi menurut Suryabrata (dalam Djaali 2011: 101) "Motivasi adalah keadaan yang terdapat dalam diri seseorang yang mendorongnya untuk melakukan aktivitas tertentu guna pencapaian suatu tujuan". Terkait dari pengertian di atas motivasi atau dorongan memiliki peran yang sangat kuat dalam menentukan terwujudnya suatu perbuatan yang direncanakan. Sedangkan motivasi menurut Ormrod (2008: 58) adalah sesuatu yang menghidupkan (energize), mengarahkan dan mempertahankan perilaku; motivasi membuat siswa bergerak, menempatkan mereka dalam suatu arah tertentu, dan menjaga mereka agar terus bergerak. Keterlibatan orangtua yang aktif dapat memberi efek positif pada berbagai aspek pendidikan termasuk meningkatkan perilaku anak dan adaptasi sosial, mengurangi masalah kedisiplinan di sekolah, meningkatkan kesuksesan di sekolah, dan peningkatan kehadiran di sekolah. Partisipasi orangtua merupakan keterlibatan secara nyata dalam suatu kegiatan. Partisipasi tersebut dapat berupa gagasan, kritik membangun, dukungan dan pelaksanaan pendidikan.

Hal ini seperti dijelaskan dalam Peraturan Menteri Pendidikan dan Kebudayaan Nomor. 30 Tahun 2017 Tentang Pelibatan Keluarga Pada Penyelenggaraan Pendidikan yaitu dalam Pasal 6, bahwa Bentuk Pelibatan Keluarga pada Satuan Pendidikan sebagaimana dimaksud dalam Pasal 5 huruf a dapat berupa: a) 
menghadiri pertemuan yang diselenggarakan oleh Satuan Pendidikan; b) mengikuti kelas Orang Tua/Wali; c) menjadi narasumber dalam kegiatan di Satuan Pendidikan. Sehingga peran keluarga dalam hal ini orangtua sangat besar sekali untuk mendukung pendidikan yang dilaksanakan dapat berhasil. Selain itu kerjasama antara pihak sekolah dan orangtua juga sangat di perlukan untuk mendukung keberhasilan penyelenggaraan pendidikan di sekolah.

Program pelibatan orangtua yang sudah dilaksanakan di SD Negeri 10 Pangkalanbaru yaitu kegiatan parenting, pertemuan paguyuban orangtua masing-masing siswa, kegiatan rutin pertemuan dengan pihak orangtua yang dilaksanakan setiap ajaran baru, program bantuan untuk siswa-siswa yang kurang mampu, serta gerakan orangtua mengajar. Program ini dilaksanakan untuk memberikan kesadaran kepada orangtua akan pentingnya pendidikan untuk anak-anak mereka. Pendidikan yang dilaksanakan di sekolah tidak akan berhasil tanpa dukungan dan bantuan dari orangtua peserta didik. Orangtua peserta didik merupakan mitra yang memberikan kontribusi yang sangat besar demi kemajuan pendidikan di sekolah.

Kegiatan atau program gerakan orangtua mengajar yang dilaksanakan di SD Negeri 10 Pangkalanbaru mengambil tema tentang hari karir (career day). Hari karir ini bersifat keahlian yang diberikan sesuai dengan profesi orangtua peserta didik. Orangtua peserta didik yang memiliki keahlian profesi ikut terlibat dalam berpartisipasi di sekolah. Pemberdayaan karir orangtua untuk meningkatkan mutu pembelajaran. Kegiatan ini merupakan kegiatan pembelajaran yang melibatkan orangtua yang memiliki profesi yang berkaitan dengan materi pembelajaran. Selain itu program ini juga disesuaikan dengan muatan kurikulum yang dilaksanakan di sekolah. Sehingga program ini benar-benar dapat memberikan manfaat untuk dapat mengembangkan program pembelajaran yang dilaksanakan di SD Negeri 10 Pangkalanbaru.

Program hari karir ini memperkenalkan beberapa profesi kepada peserta didik. Profesi orangtua yang dikenalkan kepada peserta didik tersebut antara lain profesi nelayan yang bekerjasama dengan Dinas Perikanan. Mereka dilibatkan untuk memberikan sosialisasi tentang cara menangkap ikan dengan menggunakan alat pancing, jala/jaring, puket, bubuh dan dengan cara menyelam dengan menggunakan senapan tombak. Dengan menggunakan peralatan tersebut salah satu tujuannya adalah untuk dapat melestarikan lingkungan dan tidak menyebabkan punahmya ekosistem laut. Profesi sebagai nelayan tersebut dapat mendukung pembelajaran ilmu pengetahuan alam (IPA). Selain itu dari pihak Dinas Perikanan memberikan penyuluhan kepada peserta didik akan manfaat mengkonsumsi ikan dan menjelaskan jenis-jenis ikan.

Profesi yang dikenalkan kepada peserta didik yang lain yaitu profesi polisi Pengenalan profesi sebagai polisi dilakukan dalam rangka untuk menumbuhkan kesadaran peserta didik akan pentingkan mentaati peraturan dalam berlalu lintas. Program ini dilaksanakan oleh pihak sekolah bekerjasama dengan pihak kepolisian setempat untuk mendukung program sekolah. Program ini cukup diminati peserta didik karena peserta didik diajar langsung oleh ahli yang sesuai dengan profesinya. Ada pula orangtua peserta didik yang memberikan sumbangan keahlian sebagai seorang pedagang. Orangtua yang berprofesi sebagai pedagang begitu antusias untuk menceritakan bagaimana caranya untuk menjadi seorang pedagang yang sukses. Mereka menceritakan kepada peserta didik dengan memberikan cara-cara atau langkah-langkah yang harus dipersiapkan sebelum kita akan memulai berdagang, misalnya: kita harus mengetahui barang apa yang belum banyak dijual oleh masyarakat. Kemudian kita juga harus menyiapkan modal awal untuk usaha yang akan kita lakukan. Profesi yang dikenalkan sebagai seorang pedagang dapat dikaitkan dengan materi pembelajaran dalam bidang Ilmu Pengetahuan Sosial (IPS).

Selain itu ada juga orangtua yang berprofesi sebagai penambang timah yang ikut berpartisipasi dalam program gerakan orangtua mengajar. Orangtua berbagi pengalaman dalam profesi tersebut dengan menjelaskan kepada peserta didik bagaimana caranya menambang timah tanpa harus merusak ekosistem alam. Partisipasi keahlian dalam career day sangat membantu guru dalam menyampaikan materi pelajaran khususnya yang berkaitan dengan profesi tertentu. Peserta didik juga merasa senang karena langsung bertemu dengan orangtua yang memiliki profesi tertentu dan juga memotivasi peserta didik untuk meraih cita-cita. Sehingga dengan dilaksanakan kegiatan gerakan orangtua mengajar tersebut dapat menjadi wadah bagi sekolah untuk memberikan layanan bagi peserta didik dalam bidang pengembangan profesi. 


\section{Hasil Implementasi Gerakan Orangtua Mengajar}

Hasil penelitian menunjukkan bahwa program gerakan orangtua mengajar di SD Negeri 10 Pangkalanbaru sangat efektif dan sangat menarik dilaksanakan untuk meningkatkan motivasi belajar peserta didik. Hal ini dapat dilihat dari dukungan yang sangat besar baik dari pihak sekolah yaitu kepala sekolah, guru, dan pegawai. Selain itu program gerakan orangtua mengajar ini juga di dukung dengan baik oleh orangtua peserta didik. Orangtua peserta didik yang dilibatkan untuk menjadi narasumber dalam program ini sangat tertarik dan sangat serius dalam menyiapkan materi yang harus disampaikan di depan paserta didik di sekolah. Selain itu orangtua peserta didik juga sangat senang diundang oleh pihak sekolah untuk mendukung program gerakan orangtua mengajar tersebut.

Program gerakan orangtua mengajar ini merupakan salah satu program yang dapat dilaksanakan secara berkelanjutan dan dapat dilaksanakan setiap tahun untuk dapat meningkatkan mutu dan kualitas lulusan peserta didik di SD Negeri 10 Pangkalan baru. Sebab hasil informasi yang diperoleh dari Kantor Lurah Batu Belubang Kecamatan Pangkalanbaru, bahwa angka putus sekolah yang ada di wilayah tersebut masih banyak. Rata-rata anak-anak yang tamat Sekolah Dasar tidak melanjutkan sekolah kejenjang yang lebih tinggi tetapi anak-anak tersebut tamat Sekolah Dasar ada yang langsung menikah ada juga yang langsung bekerja sebagai nelayan, pedagang, dan penambang timah. Diharapkan dari program gerakan orangtua mengajar ini dapat meningkatkan motivasi belajar peserta didik dan dapat mengurangi angka putus sekolah terutama di SD Negeri 10 Pangkalanbaru yang wilayahnya terletak di daerah pesisir Desa Batu Belubang Kecamatan Pangkalanbaru, Bangka Tengah.

Penelitian yang pernah dilakukan oleh Umar (2015) meneliti "Peranan Orangtua dalam Peningkatan Prestasi Belajar Anak". Penelitian Umar bertujuan untuk mengetahui sejauhmana peranan orangtua dalam memberikan pendidikan kepada anak untuk meningkatkan prestasi belajar anak. Simpulan penelitian Umar adalah Orangtua berperan penting dalam menentukan keberhasilan pendidikan anak-anak mereka. Induk peran dan tanggung jawab antara lain dapat diwujudkan dengan membimbing kelangsungan anak belajar di rumah sesuai dengan program yang telah dipelajari oleh anak-anak di sekolah belajar.

Orangtua dan sekolah merupakan dua unsur yang saling berkaitan dan memiliki keterkaitan yang kuat satu sama lain. Terlepas dari beragamnya asumsi masyarakat, ungkapan "buah tak akan pernah jauh jatuh dari pohonnya" adalah sebuah gambaran bahwa betapa kuatnya pengaruh orangtua terhadap perkembangan peserta didik. Supaya orangtua dan sekolah tidak salah dalam memberikan pendidikan maka harus terjalin kerjasama yang baik di antara kedua belah pihak. Orangtua mendidik peserta didik di rumah, dan di sekolah untuk mendidik peserta didik diserahkan kepada pihak sekolah atau guru. Supaya dapat berjalan dengan baik maka kerjasama di antara orangtua dan sekolah harus ada dalam suatu rel yang sama supaya bisa seiring seirama dalam memperlakukan peserta didik, baik di rumah ataupun di sekolah sesuai dengan kesepahaman yang telah disepakati oleh kedua belah pihak dalam memperlakukan peserta didik.

Dengan adanya program gerakan orangtua mengajar di SD Negeri 10 Pangkalanbaru maka dapat memberikan nilai lebih terhadap sekolah tersebut, hal ini disebabkan gerakan orangtua mengajar yang telah dilakukan di SD Negeri 10 Pangkalanbaru membawa dampak yang positif. Dampak yang positif tersebut tidak hanya berpengaruh terhadap hasil prestasi belajar peserta didik yang meningkat tetapi juga terhadap tingkat kesadaran orangtua yang meningkat. Orangtua menjadi lebih memperhatikan pentingnya pendidikan untuk anak-anak mereka serta orangtua menjadi lebih peduli dalam mendukung program-program yang dilakukan oleh pihak sekolah. Orangtua juga mulai menyadari pentingnya pendidikan untuk anak-anak mereka sebagai langkah untuk meraih cita-cita dan masa depan yang lebih baik.

Pihak sekolah yaitu SD Negeri 10 Pangkalanbaru juga mulai merasakan dampak yang baik dan positif dengan dilaksanakan program gerakan orangtua mengajar tersebut. Sekolah dapat lebih meningkatkan layanan kepada masyarakat dalam memberikan layanan dalam bidang pendidikan serta sekolah dapat meningkatkan kemitraan dengan pihak-pihak yang dapat mendukung gerakan orangtua mengajar tersebut. Pihak yang sudah diajak bekerjasama untuk mendukung antara lain Dinas Perikanan, Puskesmas, Kepolisian, Guru, Dinas Pendidikan, Kampus STKIP Muhammadiyah Bangka Belitung, serta orangtua peserta didik 
yang menjadi peran penting dalam pelaksanaan program tersebut. Pihak-pihak tersebut siap untuk membantu pelaksanaan program-program sekolah demi meningkatkan mutu dan kualitas pendidikan untuk peserta didik di SD Negeri 10 Pangkalbaru.

\section{Rencana Tindak Lanjut Terhadap Hasil Penelitian}

Program gerakan orangtua mengajar yang sudah dilaksanakan di SD Negeri 10 Pangkalanbaru mendapatkan tanggapan dan dukungan yang baik dari berbagai pihak. Pihak yang sangat berperan dalam program ini yaitu orangtua peserta didik. Disamping itu pihak sekolah yaitu guru dan kepala sekolah serta para peserta didik juga sangat senang dengan adanya program tersebut. Sehingga peneliti memberikan rancangan program kepada pihak sekolah untuk dapat melaksanakan program gerakan orangtua mengajar tersebut dengan model yang berbeda. Program tindaklanjut tersebut di buat untuk dapat meningkatkan mutu program sekolah yang berbasis pada Manajemen Berbasis Sekolah. Sehingga diharapkan dengan program tersebut masih dapat dilaksanakan secara berkelanjutan dan dapat meningkatkan program-program yang lain khususnya program yang dapat menunjang kegiatan belajar mengajar.

Program berkelanjutan gerakan orangtua mengajar ini juga dirancang dengan tujuan untuk dapat mengurangi angka putus sekolah sehingga apabila program ini dapat berjalan dengan baik, maka peneliti yakin peserta didik di SD Negeri 10 Pangkalanbaru dapat tumbuh kesadaran dan lebih memiliki motivasi yang tinggi untuk melanjutkan pendidikan yang lebih tinggi dan untuk dapat mewujudkan apa yang menjadi citacita mereka. Program sekolah akan dapat berhasil apabila program tersebut menarik dan bermanfaat terutama bagi peserta didik. Program berkelanjutan Gerakan Orangtua Mengajar tersebut adalah Parenting Day dan Career Day (Hari Kerja). Program yang akan dilaksanakan dalam gerakan orangtua mengajar adalah parenting day dan hari karir (Career day). Hari karir adalah salah satu bentuk pelaksanaan pendidikan karir di sekolah. Hari karir adalah pada hakikatnya adalah program pemberian informasi karir. Program hari karir ini di berikan dengan memanfaatkan waktu sehari penuh sekolah, atau bila memungkinkan sebagian dari hari sekolah.

Program kegiatan hari karir digunakan untuk memperkenalkan dunia kerja melalui narasumber yaitu orangtua peserta didik. Peran atau tugas orangtua dalam program ini adalah, orangtua diminta untuk menumbuhkan semangat dan motivasi belajar peserta didik melalui pengalaman kesuksesan yang sudah diperoleh selama ini. Program ini akan dimasukkan kedalam program sekolah yang secara rutin akan dilaksanakan setiap tiga bulan sekali. Peserta didik yang akan mengikuti kegiatan ini juga akan dijadwalkan secara rutin mulia dari kelas rendah (kelas 1,2,3) kemudian kelas tinggi (kelas 4,5,6). Orangtua yang akan diundang dalam kegiatan ini juga diundang secara bergantian sehingga kegiatan ini akan melibatkan semua orangtua serta wali murid masing-masing kelas. Seperti yang dijelaskan oleh Morrison (2012: 375) mengatakan bahwa, pelibatan orangtua/keluarga adalah sebuah proses membantu orangtua dan anggota keluarga menggunakan kemampuan mereka demi kepentingan anak. Keluarga, anak dan program merupakan semua bagian dari proses, sehingga semua harus diuntungkan oleh program keterlibatan yang terencana dengan baik.

\section{SIMPULAN DAN SARAN}

Simpulan yang dapat disampaikan dari hasil penelitian ini adalah bahwa implementasi gerakan orangtua mengajar yang sudah dilaksanakan di SD Negeri 10 Pangkalanbaru sudah dapat berjalan dengan baik dan efektif. Program gerakan orangtua mengajar yang sudah dilaksanakan di SD Negeri 10 Pangkalan baru juga mendapatkan dukungan dari berbagai pihak. Pihak yang mendukung program tersebut berasal dari berbagai lembaga dan instansi antara lain: dari pihak sekolah, orangtua, Dinas Pendidikan, Dinas Perikanan, Kepolisian, Puskesmas, Kampus STKIP Muhammadiyah Bangka Belitung serta dari masyarakat setempat. Dengan adanya dukungan dari berbagai pihak tersebut, program gerakan orangtua mengajar dapat dilaksanakan dengan baik serta dapat menghasilkan dampak yang positif terutama untuk peserta didik dan orangtua.

Program Gerakan orangtua mengajar yang sudah dilakukan oleh pihak SD Negeri 10 Pangkalanbaru dapat memberikan pengaruh yang positif yaitu meningkatnya motivasi belajar peserta didik, misalnya yaitu peserta didik menjadirajin berangkat ke sekolah dan peserta didik tidak terlambat untuk masuk sekolah. Selain itu program gerakan orangtua mengajar dapat menurunkan angka putus sekolah terutama 
untuk peserta didik yang ada di Wilayah Pesisir Pantai Batu Belubang khususnya peserta didik yang sekolah di SD Negeri 10 Pangkalanbaru.

Program gerakan orangtua mengajar ini juga akan dilaksanakan secara rutin oleh pihak SD Negeri 10 Pangkalanbaru. Hal ini dilakukan karena program yang sudah dilaksanakan memberikan dampak yang positif baik untuk peserta didik, orangtua dan pihak sekolah. Sehingga program gerakan orangtua mengajar ini akan terus dilanjutkan dan akan rutin dilaksnakan untuk meningkatkan mutu dan kualitas sekolah serta untuk meningkatkan kualitas lulusan peserta didik di SD Negeri 10 Pangkalanbaru. Program gerakan orangtua mengajar ini juga dapat menunjang untuk dapat mewujudkan sekolah yang berbasis pada Manajeman Berbasis Sekolah di SD Negeri 10 Pangkalanbaru.

\section{DAFTAR RUJUKAN}

Altschul, I. (2011). Parental Involvement and Academic Achievement of Mexican American Youths: What Kinds of Involvement in Youths' Education Matter Most?. Social Work Research, 35, 3, 159170.

Djaali. (2011). Psikologi Pendidikan. Jakarta: Bumi Aksara.

Junianto W, Wagiran. (2013). "Pengaruh Kinerja Mengajar Guru, Keterlibatan Orangtua,
Aktualisasi Diri dan Motivasi Berprestasi Terhadap Prestasi”. Jurnal Pendidikan Vokasi. Vol 3, Nomor 3, November 2013.

Morrison George S. (2012). Dasar-Dasar Pendidikan Anak Usia Dini (PAUD). Jakarta: PT Indeks.

Ormrod Jeanne ellis. (2008). Psikologi Pendidikan Membantu Siswa Tumbuh dan Berkembang. Jakata: Erlangga.

Peraturan Menteri Pendidikan dan Kebudayaan Nomor. 30 Tahun 2017 Tentang Pelibatan Keluarga pada Penyelenggaraan Pendidikan.

Sugiyono. (2016). Memahami Penelitian Kualitatif. Bandung: Alfabeta.

Slavin, R. E. (2011). Psikologi Pendidikan Teori dan Praktek (9th ed) jilid 1. Jakarta. Indeks.

Umar M. (2015). "Peranan Orang Tua dalam Peningkatan Prestasi Belajar Anak". Jurnal Ilmiah Edukasi. Vol. 1. Nomor. 1, Juni 2015.

Wentzel, K., \& Wigfield, A. 2009. Handbook Motivation at School. New York: Routhledge. 